\title{
Energy Supplementation during the Last Third of Gestation Improves Mother-Young Bonding in Goats
}

\author{
Juan M. Vázquez-García ${ }^{1,2}$, Gregorio Álvarez-Fuentes ${ }^{3, *}$, Héctor O. Orozco-Gregorio ${ }^{1}$, Juan C. García-López ${ }^{3}$, \\ Milagros González-Hernández ${ }^{1}$ and César A. Rosales-Nieto ${ }^{1}$ (D) \\ 1 Facultad de Agronomía y Veterinaria, Universidad Autónoma San Luis Potosí, San Luis Potosí 78321, Mexico; \\ manuelvazquez87@yahoo.com.mx (J.M.V.-G.); gohector72@yahoo.com.mx (H.O.O.-G.); \\ milagros.gonzales@uaslp.mx (M.G.-H.); cesar.rosales@uaslp.mx (C.A.R.-N.) \\ 2 Asociación Mexicana de Criadores de Ganado Caprino de Registro, San Luis Potosí 78433, Mexico \\ 3 Instituto de Investigaciones de Zonas Desérticas, Universidad Autónoma de San Luis Potosí, \\ San Luis Potosí 78377, Mexico; jcgarcia@uaslp.mx \\ * Correspondence: gregorio.alvarez@uaslp.mx
}

Citation: Vázquez-García, J.M.; Álvarez-Fuentes, G.; Orozco-Gregorio, H.O.; García-López, J.C.; González-Hernández, M.; Rosales-Nieto, C.A. Energy Supplementation during the Last Third of Gestation Improves Mother-Young Bonding in Goats. Animals 2021, 11, 287. https:// doi.org/10.3390/ani11020287

Academic Editors:

Antonio Gonzalez-Bulnes and Víctor Hugo Parraguez Gamboa

Received: 17 December 2020

Accepted: 20 January 2021

Published: 23 January 2021

Publisher's Note: MDPI stays neutral with regard to jurisdictional claims in published maps and institutional affiliations.

Copyright: (c) 2021 by the authors. Licensee MDPI, Basel, Switzerland. This article is an open access article distributed under the terms and conditions of the Creative Commons Attribution (CC BY) license (https:/ / creativecommons.org/licenses/by/ $4.0 /)$.
Simple Summary: The last third of gestation is a period of high energy demand for the dam, because she needs to support the growth of fetuses and the newborn. Moreover, towards the end of gestation, maternal feed intake is reduced as the mass of the fetoplacental unit increases. The maternal diet often cannot meet nutritional requirements, compromising thermoregulatory capacity, wellbeing, and viability, and the survival of the newborn. We have shown that energy supplementation of the mother during the last third of gestation does not affect progeny birth weight but enhances mother-young bonding.

Abstract: We tested whether maternal energy supplementation during the last third of gestation improves birth weight, neonatal wellbeing, and mother-young bonding. Thirty-six pregnant French Alpine goats were randomly allocated among three nutritional treatments for the last third of pregnancy: (i) Control, fed alfalfa (T-0; $n=12)$; (ii) alfalfa $+150 \mathrm{~g} /$ head daily energy concentrate (T-150; $n=12)$; (iii) alfalfa $+300 \mathrm{~g} /$ head daily energy concentrate $(\mathrm{T}-300 ; n=12)$. At birth, we collected progeny data on birth weight, birth type, sex, rectal temperature, heart rate, respiratory rate, time to standing, time to udder connection, and time to first feeding. For the dams, we collected data on the duration of labor, time to clean the progeny, and time to allow first suckling. At birth, body weight, rectal temperature, heart rate, and the respiratory rate did not differ among treatments $(p>0.05)$. In the dams, labor duration was not affected by the treatments $(p>0.05)$. The T-150 dams were faster to clean the newborn and allow first suckling $(p<0.05)$. The T-150 progeny were faster to stand and the T-300 progeny were faster to connect to the udder $(p<0.05)$. We conclude that energy supplementation of the dam during the last third of gestation does not affect the birth weight of the progeny, but enhances the mother-young bonding.

Keywords: goats; gestation; energy supplementation; maternal behavior; neonatal behavior

\section{Introduction}

Goats are distributed across diverse geographical and agro-ecological zones around the world, with nearly 95\% of them found in developing countries [1]. Importantly, goats are used for the production of milk and meat, and are usually the principal source of income in low-input farming systems [2]. Mexico, for example, has almost 9 million goats, mostly in arid and semi-arid conditions, that contributed to the economy in 2019 by producing nearly 40,000 tons of meat [3]. Although they are very resilient animals, their fertility rate can be reduced to $70 \%$ when the nutritional requirements are not met, with females that conceive losing fetuses, resulting in a kidding rate of about $50 \%$. This is a significant economic loss and animal welfare issue for the industry [4,5]. The combination 
of undernutrition and poor health leads to low reproductive efficiency and genetic pressure on survival rather than productivity.

With respect to nutrition, the last third of gestation and early lactation are of interest because they are periods of high maternal energy demand to support the growth of fetuses and the newborn [6,7]. Around $75 \%$ of fetal growth occurs in this period and, to make matters worse, feed intake is reduced towards the end of gestation because the growth of the fetoplacental unit restricts rumen capacity $[8,9]$. When the nutritional requirements are not met, the transfer of energy, protein, and essential nutrients from the mother to the fetus are reduced, compromising fetal growth and development $[8,10]$. Ultimately, the fetus can adapt to these nutritional challenges by modulating growth, but birth weight is reduced [11-13]. Moreover, nutritional constraints disrupt metabolic endocrine activity in the dam, leading to a catabolic state $[14,15]$ that is associated with inadequate mammary gland development and prolonged labor. The outcome for the neonate is a poor ability to stand and suck, coupled with low quantity and quality of colostrum and milk-a situation magnified as the number of fetuses increases [16-19]. Importantly, colostrum and milk yield is correlated with mother-young bonding at birth, neonatal survival, and postnatal growth [20-23].

From birth, the newborn quickly adapts to the extra-uterine environment by modifying its homeothermy mechanisms - core body temperature, heart rate, and respiration rate $[24,25]$. Despite these adaptational processes, most neonatal mortality occurs from birth to $72 \mathrm{~h}$ post-partum, with the greatest proportion seen in twin births and larger litters [26]. Immediately after birth, the mother and the neonate establish a strong and selective bond that is initially mediated by olfactory, auditory, and visual signals, and then reinforced during early lactation by the consumption of colostrum and milk [27]. Nevertheless, poor mother-young bonding and perinatal kid loss are strongly associated with low birth weight and mismothering [28]. Importantly, maternal undernutrition during gestation can compromise fetal thermoregulatory capacity and, consequently, reduce the wellbeing and viability of the neonate [29-31]. Moreover, in addition to the effects of low neonatal weight and wellbeing on mortality [26,32], there will be a reduction in postnatal growth that can have life-long effects on reproductive efficiency [33-35].

Considering this situation, it is clearly necessary to develop simple, low-cost strategies that will allow goat farmers to increase the productivity and reproductive efficiency of their animals. Such strategies will precisely coordinate nutritional inputs with the stages of the reproductive process to ensure that the metabolic signals are appropriate for optimizing the wellbeing and vitality of the neonate. Energy supplementation two weeks before parturition has been reported to increase colostrum quality and neonatal survival [36,37], but it is not known whether the benefits for the newborn are due to improvements in its wellbeing, vigor, or postnatal growth. We, therefore, tested whether gestational energy supplementation during the last third of pregnancy would improve birth weight, neonatal wellbeing, and mother-young bonding in goats.

\section{Materials and Methods}

\subsection{Ethics Statement}

This study was conducted during the breeding period at the Caprino Genetic Improvement Center in northern Mexico $\left(22^{\circ} 15^{\prime} \mathrm{N}, 100^{\circ} 52^{\prime} \mathrm{W}\right)$. All procedures were consistent with the International [38] and National [39] Research Council's Guide for the Care and Use of Laboratory Animals. The Bioethics Committee of the Faculty of Agronomy and Veterinary Medicine of the UASLP approved this experiment (reference number C19-FAI-05-0.3.03).

\subsection{Animals and Experimental Procedure}

From 55 multiparous French Alpine goats that had been naturally mated with experienced bucks for 42 days (two full reproductive cycles), 36 females on the same day of pregnancy were selected and, along with their progeny (32 females and 31 males), were used to investigate the effect of energy supplementation during the last third of gestation 
(from day 100 of pregnancy to delivery) on birth weight, neonatal wellbeing, and motheryoung bonding. All goats were managed, including deworming and vitamin supplements, according to the standard procedures of the Genetic Improvement Center, and they had free access to clean water and a block of mineral salts containing at least $17 \% \mathrm{P}, 3 \% \mathrm{Mg}, 5 \%$ $\mathrm{Ca}$, and $75 \% \mathrm{NaCl}$.

Pregnancy, number of fetuses, and gestational age were assessed three times, between 30 and 45 days after the start of mating, by transabdominal ultrasonography (SamsungMedison SA-600 fitted to a $4 \mathrm{MHz}$ convex probe; Samsung Co. Seoul, Korea). Gestational age was estimated by assessing fetometric parameters: uterine depth (in early pregnancy), fetal crown-rump length, fetal biparietal diameter, and calcification of the fetal ribs and skull [40-42].

\subsection{Experimental Diets}

On estimated gestational day $100 \pm 4$, the goats were randomly allocated among three $120 \mathrm{~m}^{2}$ pens, one for each dietary treatment, ensuring the average body weights of the groups were similar. The treatments were T- 0 (control, receiving alfalfa ad libitum; $n=12$; $56.8 \pm 1.9 \mathrm{~kg}$ ); T-150 (alfalfa ad libitum $+150 \mathrm{~g} /$ head daily energy concentrate; $n=12$; $56.9 \pm 1.7 \mathrm{~kg}$ ) and T-300 (alfalfa ad libitum $+300 \mathrm{~g} /$ head daily energy concentrate; $n=12$; $55.5 \pm 1.7 \mathrm{~kg}$ ). The nutritional content of the diet and the energy concentrate is reported in Table 1. The dry matter intake for the treatment groups was calculated based on the nutrient requirements for a $50 \mathrm{~kg}$ pregnant goat with low physical activity [43]. In T-150 and T-300, the energy supplement was provided daily at 07:00 $\mathrm{h}$. To ensure that each goat consumed only its corresponding ration of supplement, the feeders had individual traps so the hierarchy of the dams was controlled at the time of supplementation.

Table 1. Nutrient composition (Dry Matter basis) of the diets offered to pregnant goats during the last third of gestation, compared with the nutrient requirements for a $50 \mathrm{~kg}$ pregnant goat with low physical activity [43].

\begin{tabular}{|c|c|c|c|c|}
\hline & \multirow[b]{2}{*}{ NRC Requirements } & \multicolumn{3}{|c|}{ Treatment } \\
\hline & & T-0 & $\mathrm{T}-150$ & $\mathrm{~T}-300$ \\
\hline Energy supplement g & & 0 & 150 & 300 \\
\hline Alfalfa & & ad libitum & ad libitum & ad libitum \\
\hline ME (Mcal) & 4.06 & 2.68 & 3.09 & 3.5 \\
\hline Protein $(\%)$ & 18.3 & 13.5 & 16 & 18.5 \\
\hline \multicolumn{5}{|c|}{ Energy supplementation } \\
\hline \multicolumn{5}{|c|}{ Ingredient composition (\% in diet) } \\
\hline \multicolumn{3}{|c|}{ Cracked shelled corn } & \multicolumn{2}{|r|}{10.0} \\
\hline \multicolumn{3}{|c|}{ Bakery waste } & \multicolumn{2}{|r|}{35.1} \\
\hline \multicolumn{3}{|c|}{ Cornhusk } & \multicolumn{2}{|r|}{22.8} \\
\hline \multicolumn{3}{|c|}{ Soymeal } & \multicolumn{2}{|r|}{10.0} \\
\hline & Brewers dry grains & & \multicolumn{2}{|r|}{10.0} \\
\hline & Cottonseed & & \multicolumn{2}{|r|}{5.0} \\
\hline & Molasses & & \multicolumn{2}{|r|}{5.0} \\
\hline & Minerals & & \multicolumn{2}{|r|}{2.0} \\
\hline \multicolumn{5}{|c|}{ Nutrient composition of the energy supplement } \\
\hline \multicolumn{3}{|c|}{$\mathrm{ME} \mathrm{Mcal/kg}$} & \multicolumn{2}{|r|}{2.75} \\
\hline \multicolumn{3}{|c|}{$\mathrm{CP} \%$} & \multicolumn{2}{|r|}{17.0} \\
\hline \multicolumn{3}{|c|}{$\mathrm{NDF} \%$} & \multicolumn{2}{|r|}{20.1} \\
\hline \multicolumn{3}{|c|}{$\mathrm{ADF} \%$} & \multicolumn{2}{|r|}{7.8} \\
\hline
\end{tabular}

CP: Crude Protein; NDF: Neutral Detergent Fiber; ADF: Acid Detergent Fiber; ME: Metabolizable energy. NRC: Nutritional Requirements of Small Ruminants [43]. 


\subsection{Birth Weight and Neonatal Wellbeing}

On the day of kidding, date, sex, birth type, and birth weight were recorded. An hour and a half after the end of the kidding process, the kid rectal temperature was determined (GLA model M900 thermometer, GLA Agricultural Electronics, San Luis Obispo, CA, USA.), and the respiration and heart rates were estimated with a stethoscope (CK-A601DP-07, Spirit Medical, New Taipei City, Taiwan). A total of 66 kids were born, of which 3 died in the days after birth ( 2 from T-0 and 1 from T-150); their data were not included in the analysis.

\subsection{Mother-Young Bonding}

Maternal and neonatal behaviors were observed by an experienced operator standing approximately $10 \mathrm{~m}$ away from the new mother and its progeny. This approach was backed up with a closed-circuit system in which 6 cameras were placed on the top and side of the pens, providing a panoramic view of each pen (Kit Cctv 3 Cameras HD 720p Dyr Closed Circuit, SECUCORE, Coahuila, México). The onset of parturition was detected when the behavior of the dam began to change, with the goat moving away from the others, becoming restless (lying down, getting up, walking in circles), and vocalizing. The time of the first contractions was noted as the start of labor. The following variables were then recorded for the dams: labor duration, time to clean the newborn, and delay to first suckling. The following variables were recorded for the newborn: delay from birth to standing and delay to first connection to the udder.

\subsection{Statistical Analysis}

A Shapiro-Wilks normality test was used to show that the data were normally distributed $(p=0.2328)$. Subsequently, a completely randomized design using linear mixed model procedures (PROC-MIXED) in SAS [44] was used to analyze the data. Each goat was considered as an individual experimental unit. Labor duration, time to clean the newborn, delay to first suckling, delay to standing, and time to connect with the udder, birth weight, rectal temperature, respiratory rate, and heart rate, with treatment, birth type, and progeny sex included as fixed effects in the model. For progeny variables, birth weight data were included as a covariate.

All 2-way interactions among fixed effects and covariates were included in each model, and non-significant $(p>0.05)$ interactions were removed from the model. Finally, an analysis of orthogonal polynomials was carried out to compare treatments.

\section{Results}

\subsection{Birth Weight}

Birth weight did not differ among treatments $(p>0.05$; Table 2). Of the kids born, $49 \%$ were males and $51 \%$ were females, with the males $(3.8 \pm 0.7 \mathrm{~kg})$ heavier at birth than the females ( $3.4 \pm 0.5 \mathrm{~kg} ; p<0.01$; Table 2). Of the kids born, $21 \%$ were singletons, $60 \%$ were twins, and $19 \%$ were triplets, with the singletons tending $(p>0.05)$ to be heavier $(3.8 \pm 0.8 \mathrm{~kg})$ at birth than twins $(3.7 \pm 0.5 \mathrm{~kg})$ or triplets $(3.3 \pm 0.7 \mathrm{~kg})$. The difference did not differ statistically (Table 2). 
Table 2. Birth weight (BWT), rectal temperature (RT), heart rate (HR), and respiratory rate (RR) in the progeny from French Alpine goats that received 0 (T-0), $150 \mathrm{~g} / \mathrm{head}$ daily (T-150), or $300 \mathrm{~g} / \mathrm{head}$ daily (T-300) of energy supplement during the last third of gestation.

\begin{tabular}{|c|c|c|c|c|}
\hline & BWT (kg) & $\operatorname{RT}\left({ }^{\circ} \mathrm{C}\right) *$ & HR (ppm) * & $\mathrm{RR}(\mathrm{rpm})$ * \\
\hline Treatment $/ p$ value & 0.37 & 0.21 & 0.23 & 0.59 \\
\hline T-0 (Control) & $3.5 \pm 0.6$ & $38.5 \pm 0.6$ & $193 \pm 19$ & $69 \pm 19$ \\
\hline $\mathrm{T}-150$ & $3.7 \pm 0.7$ & $38.6 \pm 1.8$ & $182 \pm 30$ & $74 \pm 35$ \\
\hline $\mathrm{T}-300$ & $3.8 \pm 0.7$ & $38.0 \pm 1.7$ & $191 \pm 12$ & $79 \pm 20$ \\
\hline Birth type $/ p$ value & 0.15 & 0.04 & 0.69 & 0.05 \\
\hline Singleton & $3.8 \pm 0.8$ & $37.8 \pm 1.9^{b}$ & $193 \pm 19$ & $71 \pm 22^{b}$ \\
\hline Twin & $3.7 \pm 0.5$ & $38.4 \pm 0.7^{\mathrm{ab}}$ & $187 \pm 24$ & $69 \pm 22^{a b}$ \\
\hline Triple & $3.3 \pm 0.7$ & $38.9 \pm 1.1^{\mathrm{a}}$ & $190 \pm 22$ & $88 \pm 35^{\mathrm{a}}$ \\
\hline Sex $/ p$ value & 0.02 & 0.23 & 0.62 & 0.98 \\
\hline Female & $3.4 \pm 0.5^{b}$ & $38.5 \pm 0.6$ & $188 \pm 20$ & $72 \pm 20$ \\
\hline Male & $3.8 \pm 0.7^{\mathrm{a}}$ & $38.2 \pm 1.5$ & $189 \pm 26$ & $75 \pm 31$ \\
\hline $\begin{array}{l}\text { Interaction } \\
\text { treatment * Birth } \\
\text { Type }\end{array}$ & NS & NS & NS & NS \\
\hline $\begin{array}{l}\text { Interaction } \\
\text { treatment } * \text { Sex }\end{array}$ & NS & NS & NS & NS \\
\hline
\end{tabular}

* Newborn variables were assessed within the first two hours of life. Data of nutritional treatment are presented across sex and birth type of kids. Data of birth type are presented across nutritional treatment and sex of kids. Data of sex of the kids are presented across nutritional treatment and birth type. ${ }^{a, a b, b}$ Superscripts represent difference among treatment groups within variables $(p<0.05)$.

\subsection{Neonatal Wellbeing at Birth}

At birth, the average rectal temperature was $38.4^{\circ} \mathrm{C}$ (range $32-41^{\circ} \mathrm{C}$ ), the average heart rate was $188 \mathrm{bpm}$ (range 136-240 bpm), and the average respiration rate was $74 \mathrm{bpm}$ (range 36-180 bpm), and treatment did not affect these measures of neonatal wellbeing $(p>0.05$; Table 2). There were also no differences between male and female kids $(p>0.05$; Table 2), but birth type influenced heart rate and respiratory rate, with twins having lower values $(p<0.05$; Table 2$)$.

\subsection{Mother-Young Bonding}

\subsubsection{Maternal Behavior}

The average labor duration was $1.6 \mathrm{~h}$ (range 1.2-2.4 h) and did not differ among treatments $(p>0.05$; Table 3$)$. The average time to clean the newborn was $34.5 \mathrm{~min}$ (range 15-90 $\mathrm{min}$ ). Dams from the T-150 treatment cleaned the newborn faster after parturition $(p<0.001$; Table 3). The average delay to first suckling was $20.5 \mathrm{~s}$ (range 10-42 s). Compared to control values, the delay was shorter for T-150 dams but longer for T-300 dams $(p<0.001$; Table 3).

\subsubsection{Newborn Behavior}

The average time taken by newborn kids to stand was $29 \mathrm{~min}$ (range 14-50 min), with T-150 kids being faster and T-300 kids being slower compared to control kids $(p<0.001$; Table 3). The average time taken for newborn kids to connect with the udder was $11.5 \mathrm{~min}$ (range 5-20 min), with T-300 kids being faster and T-150 kids being slower, compared to control kids $(p>0.05$; Table 3$)$. 
Table 3. Mother-young bonding, assessed within the first hours of life, in French Alpine goats that had received 0 (T-0), $150 \mathrm{~g} /$ head daily (T-150), or $300 \mathrm{~g} /$ head daily (T-300) of energy supplement during the last third of gestation.

\begin{tabular}{cccccc}
\hline & DL (h) & TC (min) & DFS (sec) & TS (min) & DCU (min) \\
\hline Treatment $/ p$ value & 0.26 & 0.001 & 0.001 & 0.04 & 0.32 \\
\hline T-0 & $1.5 \pm 0.2$ & $28.8 \pm 6.1^{\mathrm{ab}}$ & $18.8 \pm 6.1^{\mathrm{b}}$ & $29.6 \pm 7.6^{\mathrm{ab}}$ & $11.8 \pm 3.5$ \\
$\mathrm{~T}-150$ & $1.6 \pm 0.4$ & $25.8 \pm 6.6^{\mathrm{b}}$ & $15.9 \pm 3.5^{\mathrm{b}}$ & $26.5 \pm 4.6^{\mathrm{b}}$ & $11.9 \pm 3.1$ \\
$\mathrm{~T}-300$ & $1.7 \pm 0.3$ & $55.5 \pm 18.3^{\mathrm{a}}$ & $29.5 \pm 6.8^{\mathrm{a}}$ & $31.1 \pm 5.5^{\mathrm{a}}$ & $10.4 \pm 3.4$ \\
\hline
\end{tabular}

Data of nutritional treatment are presented across sex and birth type of kids. Abbreviations: DL, duration of labor TC, time taken to clean the newborn; DFS, delay to first suckling; TS, time taken for the newborn to stand; DCU, delay to first connection with the udder. ${ }^{a, a b, b}$ Superscripts represent difference among treatment groups within variables $(p<0.05)$.

\section{Discussion}

Contrary to expectations, energy supplementation of multiparous female goats during the last third of gestation did not affect the birth weight of the progeny, their rectal temperature, heart rate, or respiration rate. On the other hand, mother-young bonding was improved with the T-150 supplement, as evidenced by the more rapid cleaning of the newborn and the shorter delay to standing. With respect to the delay in the first attachment to the udder, the situation was not so clear, with T-300 kids being faster and T- 150 kids being slower. In general, these observations are consistent with the expected effects of maternal energy status on mother-young bonding behaviors, the thermoregulatory capacity of the newborn, and neonatal wellbeing.

The maternal diet offered during the last third of gestation did not meet energy requirements, yet the birth weight of the progeny was not significantly affected by treatment, extending on observations by Mellado et al. [45] in crossbred goats and Laporte-Broux et al. [46] in Saanen and French Alpine goats, who also found that birth weight was not affected by maternal nutritional restriction during the last third of gestation. Conversely, He et al. [47] observed that the restriction of energy or protein intake during the last third of gestation reduced the birth weight in Liuyang goats, consistent with a reduction in the development of muscle and adipose tissue in the fetuses $[8,30,48]$. It is not clear why the report by He et al. [47] disagrees with the others. Most observations show little effect of restricted maternal nutrition on birth weight, supporting the idea that goats are very resistant to changes in food availability, and continue to be productive because they can adapt their metabolism and physiological status when the supply of energy and protein is limited [23,49-52]. The ability of goats to adapt to adverse conditions may be programmed during fetal, rather than postnatal, development, and in response to intrauterine conditions that regulate its growth [13].

\subsection{Neonate Wellbeing}

Maternal energy supplementation during the last third of gestation did not affect the rectal temperature of the neonates. A higher rectal temperature indicates a greater thermoregulatory ability to adapt to the extra-uterine environment and is associated with increased viability and survival [53]. Interestingly, rectal temperature was higher in neonatal triplets than in singletons, the difference in rectal temperature between birth type (singleton vs. twins vs. triplets) is probably related to birth weight because triplets are born $15 \%$ lighter than singletons. Our observations extend to those by Giannetto et al. [25], in neonatal sheep and goats, that rectal temperature was inversely related to birth weight. Conversely, Dwyer and Morgan [54], and Miller et al. [55] found that neonatal rectal temperature is directly related to birth weight. As previously indicated, the difference in rectal temperature at birth could be related to the degree of maturity and birth order of the newborn; the fetus that grows fastest and thus reaches mature weight sooner is the firstborn $[25,56]$. It seems likely that a low birth weight leads to the activation of the neonate's homeothermic mechanism, increasing its thermoregulatory 
capacity [57], perhaps due to the ability of brown adipose tissue to increase metabolism by the regulation of circulating metabolic hormones and metabolites [54,58-60]. Additionally, within a genotype, there is considerable genetic variation [61,62] that is likely to include rectal temperature and metabolic homeostasis at birth [54,60,63-65].

Glucose circulating in the mother and fetus would probably have been increased by the energy supplements fed during the last third of gestation, leading to an improvement in the physiological status of the neonate [66], but we did not observe any effect of the treatment on heart rate or respiration rate in the neonates. Heart rate should reflect homeostatic and nutritional status, and the development of the heart tissue [67], so it is seen as an indicator of physiological stress that itself is related to metabolic activation in the neonate [68]. The newborn loses a large amount of body heat through the skin in the first hours after parturition, as it adapts to its new environment, leading to a decrease in respiration rate [56,69]; therefore, it is possible to hypothesize that the newborns with lower respiration rate presented a better adaptation to the new environment [70]. Moreover, we found that newborn singletons had a higher heart rate than twins or triplets, whereas triplets had a higher respiratory rate than singletons or twins. Giannetto et al. [25] did not observe a significant difference in respiratory rate between singletons and twins, but they observed that the heart rate was higher in twins compared to singletons, attributing this event to the maturation of the newborn. Nevertheless, maternal energy supplementation during the last third of gestation had no consistent effects on the measures of neonatal wellbeing.

Many previous reports have shown that, at birth, males are heavier than females and singletons are heavier than twins or triplets $[9,21,22,42]$, and the present results do not disagree.

\subsection{Mother-Young Bonding}

The duration of labor increases as the weight of the progeny increases because large fetuses cause dystocia [19], affecting "maternal experience" and therefore, perhaps, motheryoung bonding. Importantly, this factor was not a problem in the present study because maternal energy supplementation during the last third of gestation did not influence the duration of labor. This clarifies the interpretation of our observation (multiparous females) since the birth weight of the progeny across the treatments was similar and that, in general, mother-young bonding was positively influenced by maternal energy supplementation during the last third of gestation. Supplemented dams had a greater maternal ability, quickly cleaning their kids, thus increasing mother-young interactions necessary for bonding. Their kids also stood and found the udder more quickly, two factors that favor the survival of the neonate [70]. In late gestation, the circulating concentration of glucose decreases leading to fat mobilization and an increase in the circulating concentration of Non-Esterified Fatty Acids [71]. These observations are consistent with the notion that the last third of gestation is a period of high maternal energy demand [7] that is compounded by a reduction in feed intake as the fetoplacental units grow, especially if there is a large number of fetuses [9]. Therefore, any increase in energy intake in the last third of gestation would be expected to increase glucose supply and promote glucose transfer from the dam and the fetus. The outcome would be an enhanced maternal oxytocin response, thus enhancing maternal behavior [24,72], and an increase in the vigor and therefore survival of the neonate $[67,70]$.

The ability of the neonate to stand and find the udder quickly may be related to an increase in the circulating concentrations of cortisol and glucose [73], leading to an increase in respiration rate that modulates homeothermic mechanisms [55]. Conversely, any delay in the newborn standing would lead to greater loss of heat and energy expenditure, resulting in hypothermia and, ultimately, death $[54,70,74]$. This interpretation is consistent with the work of Dwyer et al. $[75,76]$ who found that maternal nutritional restriction negatively impacts mother-young bonding by reducing cleaning time and increasing rejection of the neonate. Importantly, in addition to nutritional strategies, genetic strategies could be used to increase the maternal ability and progeny behavior $[70,74,77]$, strengthening the 
interactions between mother and neonate, and thus mother-young bonding, and reducing neonatal mortality.

In conclusion, maternal energy supplementation during the last third of gestation in multiparous goats did not influence birth weight and had no consistent effects on measures of neonatal wellbeing. However, it improved mother-young bonding and would thus be expected to improve neonatal survival under field conditions. Further research is needed to elucidate the impact of gestational energy supplementation on post-weaning growth and the subsequent reproductive efficiency of the progeny.

Author Contributions: Conceptualization, J.M.V.-G., G.Á.-F. and C.A.R.-N.; data curation, J.M.V.-G., G.Á.-F. and C.A.R.-N.; formal analysis, G.Á.-F.; funding acquisition, J.M.V.-G. and G.Á.-F.; investigation, J.M.V.-G. and C.A.R.-N.; methodology, H.O.O.-G. and M.G.-H.; resources, J.M.V.-G., G.Á.-F., J.C.G.-L. and C.A.R.-N.; supervision, G.Á.-F. and C.A.R.-N.; validation, J.M.V.-G., G.Á.-F., H.O.O.-G., J.C.G.-L., M.G.-H. and C.A.R.-N.; visualization, J.M.V.-G., G.Á.-F. and C.A.R.-N.; writing-original draft, J.M.V.-G.; writing-review and editing, J.M.V.-G., G.Á.-F. and C.A.R.-N. All authors have read and agreed to the published version of the manuscript.

Funding: The present study was financed by the Support Fund to Research (FAI) of the Autonomous University of San Luis Potosí Agreement number: C19-FAI-05-0.3.03.

Institutional Review Board Statement: The study was conducted according to the guidelines of the Declaration of Helsinki, and approved by the Institutional Ethics Committee of the Faculty of Agronomy and Veterinary Medicine of the UASLP (reference number C19-FAI-05-0.3.03).

Data Availability Statement: The data presented in this study are available on request from the corresponding author.

Acknowledgments: The authors thank M.C. Jorge Sánchez Ortega from the Caprino Genetic Improvement Center for allowing us to use experimental animals. We thank the Mexican Association of Goat Cattle Breeders of Record for their invaluable support for the development of the experiment. Additionally, the participation of the students of the Faculty of Agronomy and Veterinary Medicine of the UASLP who participated in the capture of experimental data is appreciated. The funds for experimenting come from the Research Support Fund (FAI) 2018-2019 UASLP. The authors are grateful to Graeme B Martin for his constructive comments to improve the manuscript.

Conflicts of Interest: The authors declare no conflict of interest.

Data Repository Resources: The data presented in the manuscript is part of the thesis entitled "Effect of diet on the maternal behavior of goats at birth, neonatal vitality and their metabolic profile", in which the first author of the manuscript is the author of the thesis. The thesis will be submitted to the Universidad Autónoma de San Luis Potosí this year.

\section{References}

1. Miller, B.A.; Lu, C.D. Current status of global dairy goat production: An overview. Asi-Aust. J. Anim. Sci. 2019, 32, 1219-1232. [CrossRef]

2. Gonzalez-Bulnes, A.; Meza-Herrera, C.A.; Rekik, M.; Ben Salem, H.; Kridli, R.T. Limiting factors and strategies for improving reproductive outputs of small ruminants reared in semi-arid environments. In Semi-Arid Environments: Agriculture, Water Supply and Vegetation; Degenovine, K.M., Ed.; Nova Science Publishers Inc.: Hauppauge, NY, USA, 2011; Chapter 2; pp. 41-60, ISBN 978-1-61761-541-2.

3. Secretaria de Agricultura y Desarrollo Rural y Servicio de Información Agroalimentaria y Pesquera (SIAP). PanoramaAgroalimentario. 2020. Available online: https://nube.siap.gob.mx/gobmx_publicaciones_siap/(accessed on 18 January 2021).

4. Mellado-Bosque, M.; González-Rodríguez, H.; García-Martínez, J.E. Body traits, parity and number of fetuses as risk factors for abortion in range goats. Agrociencia 2001, 35, 355-361.

5. Mellado, M.; Rodríguez, I.J.; Alvarado-Espino, A.; Véliz, F.G.; Mellado, J.; García, J.E. Short communication: Reproductive response to concentrate supplementation of mixed-breed goats on rangeland. Trop. Anim. Health Prod. 2020, 52, $2737-2741$. [CrossRef]

6. Pulina, G.; Macciotta, N.; Nudda, A. Milk composition and feeding in the Italian dairy sheep. Ital. J. Anim. Sci. 2004, 4, 5-14. [CrossRef]

7. Sadjadian, R.; Seifi, H.A.; Mohri, M.; Naserian, A.A.; Farzaneh, N. Variations of energy biochemical metabolites in periparturient dairy Saanen goats. Comp. Clin. Pathol. 2013, 22, 449-456. [CrossRef] 
8. Du, M.; Tong, J.; Zhao, J.; Underwood, K.R.; Zhu, M.; Ford, S.P.; Nathanielsz, P.W. Fetal programming of skeletal muscle development in ruminant animals. J. Anim. Sci. 2010, 88, E51-E60. [CrossRef]

9. Ochoa Cordero, M.; Meza Herrera, C.A.; Vázquez García, J.M.; Stewart, C.A.; Rosales Nieto, C.A.; Ochoa Alfaro, A.E.; Purvis, I.A.; Cuevas Reyes, V.; Lee, H.; Martin, G.B. Pregnancy and litter size, but not lamb sex, affect feed intake and wool production by Merino-type ewes. Animals 2019, 9, 214. [CrossRef]

10. Jenkinson, C.M.C.; Earl, A.K.; Kenyon, P.R.; Blair, H.T. Effects of maternal nutrition during pregnancy on fetal growth and maternal constraint in sheep. Anim. Prod. Sci. 2012, 52, 524-532. [CrossRef]

11. Fowden, A.L.; Ward, J.W.; Wooding, F.P.B.; Forhead, A.J.; Constancia, M. Programming placental nutrient transport capacity. J. Phys. 2006, 572, 5-15. [CrossRef]

12. Coan, P.M.; Angiolini, E.; Sandovici, I.; Burton, G.J.; Constância, M.; Fowden, A.L. Adaptations in placental nutrient transfer capacity to meet fetal growth demands depend on placental size in mice. J. Phys. 2008, 586, 4567-4576. [CrossRef]

13. Gluckman, P.D.; Hanson, M.A.; Cooper, C.; Thornburg, K.L. Effect of In Utero and Early-Life Conditions on Adult Health and Disease. N. Engl. J. Med. 2008, 359, 61-73. [CrossRef] [PubMed]

14. Caldeira, R.M.; Belo, A.T.; Santos, C.C.; Vazques, M.I.; Portugal, A.V. The effect of long-term feed restriction and over-nutrition on body condition score, blood metabolites and hormonal profiles in ewes. Small Rumin. Res. 2007, 68, 242-255. [CrossRef]

15. Tygesen, M.P.; Nielsen, M.O.; Nørgaard, P.; Ranvig, H.; Harrison, A.P.; Tauson, A.-H. Late gestational nutrient restriction: Effects on ewes' metabolic and homeorhetic adaptation, consequences for lamb birth weight and lactation performance. Arch. Anim. Nutr. 2008, 62, 44-59. [CrossRef] [PubMed]

16. Mellor, D.J.; Murray, L. Effects of maternal nutrition on the availability of energy in the body reserves of fetuses at term and in colostrum from Scottish Blackface ewes with twin lambs. Res. Vet. Sci. 1985, 39, 235-240. [CrossRef]

17. Neville, T.L.; Meyer, A.M.; Reyaz, A.; Borowicz, P.B.; Redmer, D.A.; Reynolds, L.P.; Caton, J.S.; Vonnahme, K.A. Mammary gland growth and vascularity at parturition and during lactation in primiparous ewes fed differing levels of selenium and nutritional plane during gestation. J. Anim. Sci. Biotechnol. 2013, 4, 6. [CrossRef] [PubMed]

18. Rosales Nieto, C.A.; Meza-Herrera, C.A.; Morón Cedillo, F.J.; Flores Najera, M.J.; Gámez Vázquez, H.G.; Cuevas Reyes, V.; Liu, S.M. Effects of vitamin E supply during late gestation and early lactation upon colostrum composition, milk production and quality in nutritional restricted ewes. Small Rumin. Res. 2015, 133, 77-81. [CrossRef]

19. Dutra, F.; Banchero, G. Polwarth and Texel ewe parturition duration and its association with lamb birth asphyxia. J. Anim. Sci. 2011, 89, 3069-3078. [CrossRef]

20. Nowak, R.; Porter, R.; Levy, F.; Orgeur, P.; Schaal, B. Role of mother-young interactions in the survival of offspring in domestic mammals. Rev. Reprod. 2000, 5, 153-163. [CrossRef]

21. Rosales Nieto, C.A.; Ferguson, M.B.; Macleay, C.A.; Briegel, J.R.; Wood, D.A.; Martin, G.B.; Bencini, R.; Thompson, A.N. Milk production and composition, and progeny performance in young ewes with high merit for rapid growth and muscle and fat accumulation. Animals 2018, 12, 2292-2299. [CrossRef]

22. Cuevas Reyes, V.; Santiago Hernandez, F.; Flores Najera, M.D.J.; Vazquez Garcia, J.M.; Urrutia Morales, J.; Hosseini-Ghaffari, M.; Chay-Canul, A.; Meza-Herrera, C.A.; Gonzalez-Bulnes, A.; Martin, G.B.; et al. Intake of Spineless Cladodes of Opuntia ficus-indica During Late Pregnancy Improves Progeny Performance in Underfed Sheep. Animals 2020, 10, 995. [CrossRef]

23. Flores-Najera, M.J.; Vélez-Monroy, L.I.; Sánchez-Duarte, J.I.; Cuevas-Reyes, V.; Mellado, M.; Rosales-Nieto, C.A. Milk yield and composition and body weight of offsprings of mixed-breed goats on semi-arid rangelands with different rainfall. Trop. Anim. Health Prod. 2020, 52, 3799-3808. [CrossRef] [PubMed]

24. Dwyer, C. Individual Variation in the Expression of Maternal Behaviour: A Review of the Neuroendocrine Mechanisms in the Sheep. J. Neurosci. 2008, 20, 526-534. [CrossRef] [PubMed]

25. Giannetto, C.; Arfuso, F.; Fazio, F.; Giudice, E.; Panzera, M.; Piccione, G. Rhythmic function of body temperature, breathing and heart rates in newborn goats and sheep during the first hours of life. J. Vet. Behav. 2017, 18, 29-36. [CrossRef]

26. Hinch, G.N.; Brien, F. Lamb survival in Australian flocks: A review. Anim. Prod. Sci. 2014, 54, 656-666. [CrossRef]

27. Freitas-de-Melo, A.; Ungerfeld, R.; Orihuela, A.; HÖtzel, M.J.; Pérez-Clariget, R. Restricción alimenticia durante la gestación y vínculo madre-cría en ovinas: Una revisión. Veterinaria 2018, 54, 19-28.

28. Robertson, S.M.; Atkinson, T.; Friend, M.A.; Allworth, M.B.; Refshauge, G. Reproductive performance in goats and causes of perinatal mortality: A review. Anim. Prod. Sci. 2020, 60, 1669-1680. [CrossRef]

29. Nowak, R.; Poindron, P. From birth to colostrum: Early steps leading to lamb survival. Reprod. Nutr. Dev. 2006, 46, 431-446. [CrossRef]

30. Gardner, D.S.; Buttery, P.J.; Daniel, Z.; Symonds, M.E. Factors affecting birth weight in sheep: Maternal environment. Reproduction 2007, 133, 297-307. [CrossRef]

31. Pillai, S.M.; Jones, A.K.; Hoffman, M.L.; McFadden, K.K.; Reed, S.A.; Zinn, S.A.; Govoni, K.E. Fetal and organ development at gestational days 45, 90, 135 and at birth of lambs exposed to under- or over-nutrition during gestation1,2,3. Transl. Anim. Sci. 2017, 1, 16-25. [CrossRef]

32. Scales, G.H.; Burton, R.N.; Moss, R.A. Lamb mortality, birthweight, and nutrition in late pregnancy. N. Z. J. Agric. Res. 1986, 29, 75-82. [CrossRef] 
33. Rosales Nieto, C.A.; Ferguson, M.B.; Macleay, C.A.; Briegel, J.R.; Martin, G.B.; Thompson, A.N. Selection for superior growth advances the onset of puberty and increases reproductive performance in ewe lambs. Animal 2013, 7, 990-997. [CrossRef] [PubMed]

34. Rosales Nieto, C.A.; Ferguson, M.B.; Macleay, C.A.; Briegel, J.R.; Wood, D.A.; Martin, G.B.; Thompson, A.N. Ewe lambs with higher breeding values for growth achieve higher reproductive performance when mated at age 8 months. Theriogenology 2013, 80, 427-435. [CrossRef] [PubMed]

35. Rosales Nieto, C.A.; Ferguson, M.B.; Thompson, H.; Briegel, J.R.; Macleay, C.A.; Martin, G.B.; Thompson, A.N. Relationships among Puberty, Muscle and Fat, and Liveweight Gain during Mating in Young Female Sheep. Reprod. Domest. Anim. 2015, 50, 637-642. [CrossRef] [PubMed]

36. Banchero, G.E.; Clariget, R.P.; Bencini, R.; Lindsay, D.R.; Milton, J.T.B.; Martin, G.B. Endocrine and metabolic factors involved in the effect of nutrition on the production of colostrum in female sheep. Reprod. Nutr. Dev. 2006, 46, 447-460. [CrossRef] [PubMed]

37. Ramírez-Vera, S.; Terrazas, A.; Delgadillo, J.A.; Serafín, N.; Flores, J.A.; Elizundia, J.M.; Hernández, H. Feeding corn during the last 12 days of gestation improved colostrum production and neonatal activity in goats grazing subtropical semi-arid rangeland. J. Anim. Sci. 2012, 90, 2362-2370. [CrossRef] [PubMed]

38. FASS. Guide for the Care and Use of Agricultural Animals in Agricultural Research and Teaching, 3rd ed.; Federation Animal Science Society: Champaing, IL, USA, 2010; p. 177.

39. NAM-National Academy of Medicine. Guide for the Care and Use of Laboratory Animals. Co-Produced by the National Academy of Medicine-Mexico and the Association for Assessment and Accreditation of Laboratory Animal Care International, 1st ed.; Harlan: Mexico City, Mexico, 2010.

40. González de Bulnes, A.; Santiago Moreno, J.; López Sebastián, A. Estimation of fetal development in manchega dairy ewes by transrectal ultrasonographic measurements. Small Rumin. Res. 1998, 27, 243-250. [CrossRef]

41. Abdelghafar, R.; Ahmed, B.; Ibrahim, M.; Mantis, P. Prediction of Gestational Age by Transabdominal Real-Time Ultrasonographic Measurements in Saanen Goats (Capra hircus). Glob. Vet. 2011, 6, 346-351.

42. Rosales-Nieto, C.A.; Ehrhardt, R.; Mantey, A.; Makela, B.B.; Veiga-Lopez, A. Preconceptional diet manipulation and fetus number can influence placenta endocrine function in sheep. Domest. Anim. Endocrinol. 2021, 74, 106-577. [CrossRef]

43. NRC. Nutrient Requirements of Small Ruminants, Sheep, Goats, Cervids, and New World Camelids, 1st ed.; National Academy Press: Washington, DC, USA, 2007.

44. SAS Institute. SAS/Stat User's Guide, Version 9.3; SAS Institute Inc.: Cary, NC, USA, 2010.

45. Mellado, M.; Olivares, L.; Diaz, H.; Villarreal, J.A. Placental Traits in Pen-fed Goats and Goats Kept on Rangeland. J. Appl. Anim. Res. 2006, 29, 133-136. [CrossRef]

46. Laporte-Broux, B.; Roussel, S.; Ponter, A.A.; Perault, J.; Chavatte-Palmer, P.; Duvaux-Ponter, C. Short-term effects of maternal feed restriction during pregnancy on goat kid morphology, metabolism, and behavior. J. Anim. Sci. 2011, 89, 2154-2163. [CrossRef]

47. He, Z.X.; Wu, D.Q.; Sun, Z.H.; Tan, Z.L.; Qiao, J.Y.; Ran, T.; Tang, S.X.; Zhou, C.S.; Han, X.F.; Wang, M.; et al. Protein or energy restriction during late gestation alters fetal growth and visceral organ mass: An evidence of intrauterine programming in goats. Anim. Rep. Sci. 2013, 137, 177-182. [CrossRef] [PubMed]

48. Sandoval, C.; Lambo, C.A.; Beason, K.; Dunlap, K.A.; Satterfield, M.C. Effect of maternal nutrient restriction on skeletal muscle mass and associated molecular pathways in SGA and Non-SGA sheep fetuses. Domest. Anim. Endocrinol. 2020, 72, $106-443$.

49. Silanikove, N. The physiological basis of adaptation in goats to harsh environments. Small Rumin. Res. 2000, 35, 181-193. [CrossRef]

50. Rosales Nieto, C.A.; Urrutia Morales, J.; Gamez-Vazquez, H.G.; Díaz Gómez, M.O.; Ramírez Andrad, B.M. The influence of feeding level on the reproductive activity of Mexican native goats during the reproductive season. Tec. Pec. Mex. 2006, 44, 399-406.

51. Rosales-Nieto, C.A.; Gamez-Vazquez, H.G.; Gudino-Reyes, J.; Reyes-Ramirez, E.A.; Eaton, M.; Stanko, R.L.; Meza-Herrera, C.A.; Gonzalez-Bulnes, A. Nutritional and metabolic modulation of the male effect on the resumption of ovulatory activity in goats. Anim. Prod. Sci. 2011, 51, 115-122. [CrossRef]

52. García-Monjaras, S.; Santos-Díaz, R.E.; Flores-Najera, M.J.; Cuevas-Reyes, V.; Meza-Herrera, C.A.; Mellado, M.; Chay-Canul, A.J.; Rosales-Nieto, C.A. Diet selected by goats on xerophytic shrubland with different milk yield potential. J. Arid Environ. 2021, 186, 104429. [CrossRef]

53. Symonds, M.E.; Lomax, M.A. Maternal and environmental influences on thermoregulation in the neonate. Proc. Nutr. Soc. 2007, 51, 165-172. [CrossRef]

54. Dwyer, M.; Morgan, C.A. Maintenance of body temperature in the neonatal lamb: Effects of breed, birth weight, and litter size. J. Anim. Sci. 2006, 84, 1093-1101. [CrossRef]

55. Miller, D.R.; Blache, D.; Jackson, R.B.; Downie, E.F.; Roche, J.R. Metabolic maturity at birth and neonate lamb survival: Association among maternal factors, litter size, lamb birth weight, and plasma metabolic and endocrine factors on survival and behavior. $J$. Anim. Sci. 2010, 88, 581-592. [CrossRef]

56. Aleksiev, Y. The effect of shearing on the behaviour of some physiological responses in lactating Pleven blackhead ewes. Bulg. J. Agric. Sci. 2009, 15, 446-452. 
57. Hoffman, M.L.; Reed, S.A.; Pillai, S.M.; Jones, A.K.; McFadden, K.K.; Zinn, S.A.; Govoni, K.E. Physiology and Endocrinology Symposium: The effects of poor maternal nutrition during gestation on offspring postnatal growth and metabolism. J. Anim. Sci. 2017, 95, 2222-2232. [CrossRef] [PubMed]

58. Clarke, L.; Heasman, L.; Firth, K.; Symonds, M.E. Influence of feeding and ambient temperature on thermoregulation in newborn lambs. Exp. Physiol. 1997, 82, 1029-1040. [CrossRef] [PubMed]

59. Clarke, L.; Heasman, L.; Firth, K.; Symonds, M.E. Influence of route of delivery and ambient temperature on thermoregulation in newborn lambs. Am. J. Phys. 1997, 272, 1931-1939. [CrossRef] [PubMed]

60. Plush, K.J.; Hebart, M.L.; Brien, F.D.; Hynd, P.I. Variation in physiological profiles may explain breed differences in neonatal lamb thermoregulation. Anim. Prod. Sci. 2016, 56, 746-756. [CrossRef]

61. Diez-Tascón, C.; Littlejohn, R.P.; Almeida, P.A.R.; Crawford, A.M. Genetic variation within the Merino sheep breed: Analysis of closely related populations using microsatellites. Anim. Genet. 2000, 31, 243-251. [CrossRef]

62. Mello de Araújo, A.; Facioni, G.S.E.; Medeiros, M.T.M.; Sávio, L.P.; Silva, P.C.; Riveiro daSilva, F.L.; Teixeria, R.M.; Virgínia de Souza, C.; Graca de Fonseca, C. Genetic diversity between herds of Alpine and Saanen dairy goats and the naturalized Brazilian Moxotó breed. Genet. Mol. Biol. 2006, 29, 67-74. [CrossRef]

63. Plush, K.J.; Brien, F.D.; Hebart, M.L.; Hynd, P.I. Thermogenesis and physiological maturity in neonatal lambs: A unifying concept in lamb survival. Anim. Prod. Sci. 2016, 56, 736-745. [CrossRef]

64. Rosales Nieto, C.A.; Thompson, A.N.; Martin, G.B. A new perspective on managing the onset of puberty and early reproductive performance in ewe lambs: A review. Anim. Prod. Sci. 2018, 58, 1967-1975. [CrossRef]

65. Rosales Nieto, C.A.; Ferguson, M.B.; Briegel, J.R.; Hedger, M.P.; Martin, G.B.; Thompson, A.N. Pre-pubertal growth, muscle and fat accumulation in male and female sheep-Relationships with metabolic hormone concentrations, timing of puberty and reproductive outcomes. Reprod. Domest. Anim. 2019, 54, 1596-1603. [CrossRef]

66. Haffaf, S.; Benallou, B. Changes in energetic profilr of pregnant ewes in relation with the composition of the fetal fluids. Asian Pac. J. Trop. Biomed. 2016, 6, 256-258. [CrossRef]

67. De Matteo, R.; Stacy, V.; Probyn, M.; Desai, M.; Ross, M.; Harding, R. The Perinatal Development of Arterial Pressure in Sheep: Effects of Low Birth Weight Due to Twinning. Reprod. Sci. 2008, 15, 66-74. [CrossRef] [PubMed]

68. Ross, M.G.; Desai, M.; Guerra, C.; Wang, S. Prenatal programming of hypernatremia and hypertension in neonatal lambs. J. Physiol. Regul. Integr. Comp. Physiol. 2004, 288, 97-103. [CrossRef] [PubMed]

69. Vicente-Pérez, R.; Avendaño-reyes, L.; Correa-Calderón, A.; Mellado, M.; Meza-Herrera, C.A.; Montañez-Valdez, O.D.; MacíasCruz, U. Relationships of body surface thermography with core temperature, birth weight and climaric variables in neonatal lambs born during early spring in an arid region. J. Therm. Biol. 2019, 82, 142-149. [CrossRef] [PubMed]

70. Rahman-Abdul, I.I.; Bemard, A. Vigour in west African dwarf kids within the first 24 h post-partum. Trop. Anim. Health Prod. 2017, 49, 547-553. [CrossRef] [PubMed]

71. Ehrhardt, R.A.; Slepetis, R.M.; Bell, A.W.; Boisclair, Y.R. Maternal leptin is elevated during pregnancy in sheep. Domest. Anim. Endocrinol. 2001, 21, 85-96. [CrossRef]

72. McCormack, S.E.; Blevins, J.E.; Lawson, E.A. Metabolic Effects of Oxytocin. Endocr. Rev. 2019, 41, 121-145. [CrossRef] [PubMed]

73. Symonds, M.E.; Bryant, M.J.; Clarke, L.; Darby, C.J.; Lomax, M.A. Effect of maternal cold exposure on brown adipose tissue and thermogenesis in the neonatal lamb. J. Phys. 1992, 455, 487-502. [CrossRef]

74. Matheson, S.M.; Bünger, L.; Dwyer, C.M. Genetic Parameters for fitness and neonatal behavior traits in sheep. Behav. Genet. 2012, 42, 899-911. [CrossRef]

75. Dwyer, A.B.; Lawrence, S.C.; Mitch, L. Ewe-lamb bonding behaviours at birth are affected by maternal undernutrition in pregnancy. Br. J. Nutr. 2003, 89, 123-136. [CrossRef]

76. Dwyer, C. Maternal behaviour and lamb survival: From neuroendocrinology to practical application. Animal 2015, 8, 102-112. [CrossRef]

77. Brown, D.J.; Fogarty, N.M.; Iker, C.L.; Ferguson, D.M.; Blache, D.; Gaunt, G.M. Genetics evaluation of maternal behaviour and temperament in Australian sheep. Anim. Prod. Sci. 2015, 56, 767-774. [CrossRef] 